\title{
Facial talon cusp on a permanent mandibular canine: A rare case report
}

\section{Dodatkowy guzek talon na powierzchni wargowej kła żuchwy - opis rzadkiego przypadku}

\author{
Faraz Ahmed ${ }^{A-F}$, Anupama P. Nayak ${ }^{A, D-F}$, Arathi Rao ${ }^{\mathrm{F}}$ \\ Department of Pedodontics and Preventive Dentistry, Manipal College of Dental Sciences, Manipal University, Mangalore, India \\ A - research concept and design; $\mathrm{B}$ - collection and/or assembly of data; $\mathrm{C}$ - data analysis and interpretation; \\ $D$ - writing the article; $E$ - critical revision of the article; $F$ - final approval of the article
}

\section{Address for correspondence \\ Anupama P. Nayak}

E-mail: anupama.np@manipal.edu

\section{Funding sources}

None declared

Conflict of interest

None declared

Received on April 26, 2017

Reviewed on June 10, 2017

Accepted on July 3, 2017

DOI

10.17219/dmp/75658

Copyright

() 2017 by Wroclaw Medical University

and Polish Dental Society

This is an article distributed under the terms of the

Creative Commons Attribution Non-Commercial License

(http://creativecommons.org/licenses/by-nc-nd/4.0/)

\begin{abstract}
Talon cusp is an unusual abnormality characterized by a cusp-like projection that occurs due to the evagination of enamel and dentin with a variable amount of pulp tissue before calcification, usually present on the cingulum area on the palatal and lingual surface of the anterior teeth. The maxillary lateral incisors are most often affected, followed by the maxillary central incisors in both primary and permanent dentition. The etiology is unknown. This developmental anomaly is rare on the facial surfaces of mandibular canines and very few cases have been reported. When it occurs on the facial surface, it usually affects the esthetics and functioning.

The present case report describes an unusual case of a facial talon cusp on a permanent mandibular left canine in a 12-year-old girl. To date, only 1 such case has been reported to our knowledge and it requires careful dental and radiographic examination of the affected patient since the findings can be of clinical significance.
\end{abstract}

Key words: developmental abnormality, mandibular, canine

Słowa kluczowe: zaburzenie rozwojowe, żuchwa, kieł 
Talon cusp is a developmental abnormality which is characterized by a prominent cusp on the palatal surface of maxillary and mandibular teeth. ${ }^{1}$ The prevalence of talon cusp ranges from less than $1 \%$ to $8 \%$ of the Indian population. Studies show a prevalence rate of about $7.7 \%$ in the North Indian population and $19.35 \%$ in the South Indian population. It exhibits a higher incidence in males than females at a ratio of $16: 9 .^{2}$ It is most commonly seen in maxillary teeth (94\%) with maxillary lateral incisors being most commonly affected (55\%) followed by maxillary central incisors (33\%) and canines (9\%). ${ }^{3}$ This developmental anomaly may have multiple clinical implications such as esthetic and occlusal problems, caries and displacement of the affected tooth and irritation of the tongue during mastication and speech. The occurrence of talon cusp on mandibular teeth has been found to be extremely rare. In the literature, only 1 case report has been presented, by Chinni et al., on a permanent mandibular canine. ${ }^{4}$ Thus, this case report adds 1 more case to the present literature on the labial aspect of a permanent mandibular canine, which is a very atypical condition.

\section{Case report}

A 12-year-old girl accompanied by her parents reported to the Department of Paedodontics and Preventive Dentistry with the chief complaint of pain and food lodgment in her upper front tooth for the past week. The pain was intermittent in nature and aggravated on having cold food. This was her first dental visit and the patient did not present any significant medical history. Intraoral examination showed that the lower left canine was structurally dissimilar to its antimere, having a convexity on the buccal surface (Fig. 1). The discovery of the anomaly was accidental and had nothing to do with the pain experienced by the patient. The patient did not report any problem while biting. All other teeth did not show any developmental abnormalities. The parents had no knowledge of similar anomalies in the dentitions of any other family members.

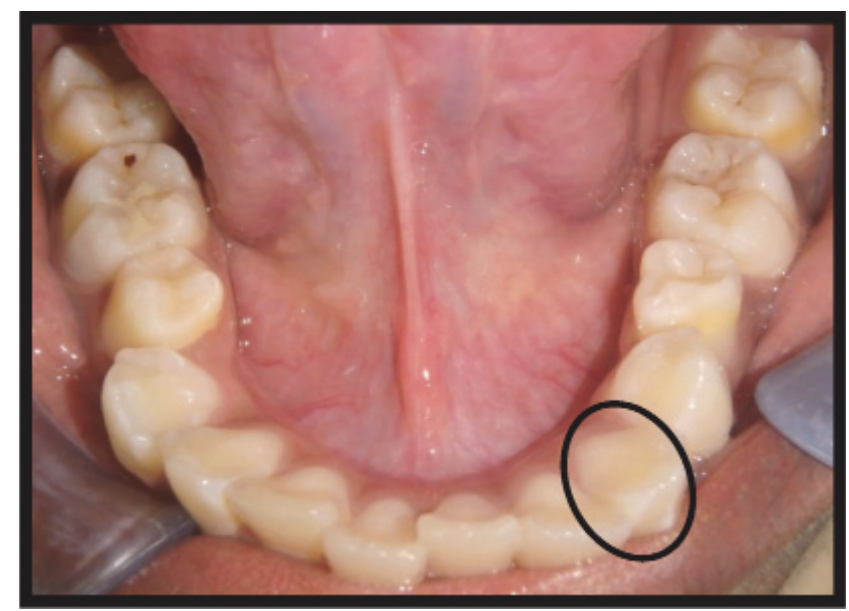

Fig. 1. Occlusal view of mandibular arch

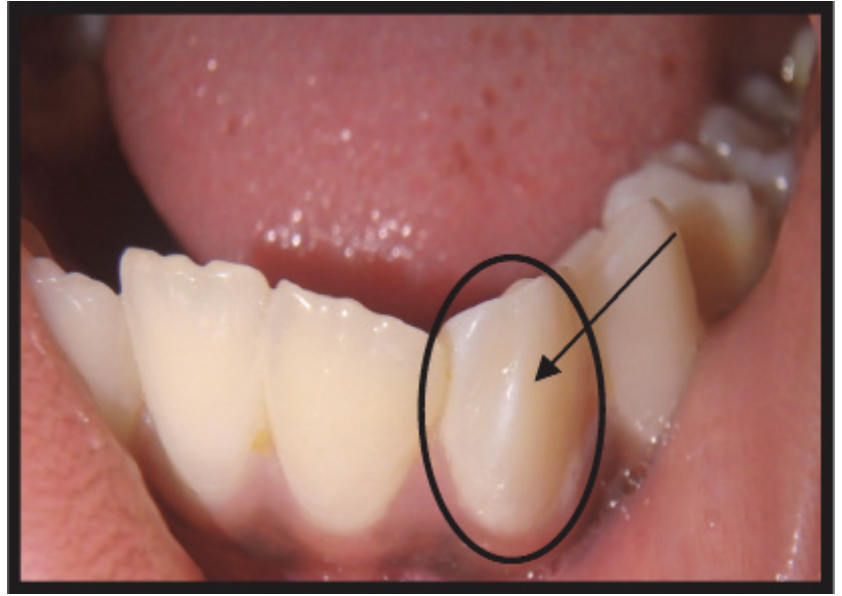

Fig. 2. Labial view of 33 showing talon cusp

Plaque and deep fissures were present in relation to the upper and lower first permanent molars.

A provisional diagnosis of talon cusp was made as the tooth with talon cusp is commonly thicker faciolingually and wider mesiodistally than the normal contralateral tooth (Fig. 2). An intraoral periapical radiograph of tooth 33 revealed a V-shaped structure with greater radiopacity in the crown, which confirmed the diagnosis of talon cusp (Fig. 3).

The management of talons cusp depends upon the case. It has been reported that just the mere existence of talon cusp is not an indication for dental treatment unless it causes clinical problems. ${ }^{5}$ In this case, the talon cusp was asymptomatic and not interfering with the occlusion, therefore no treatment was done.

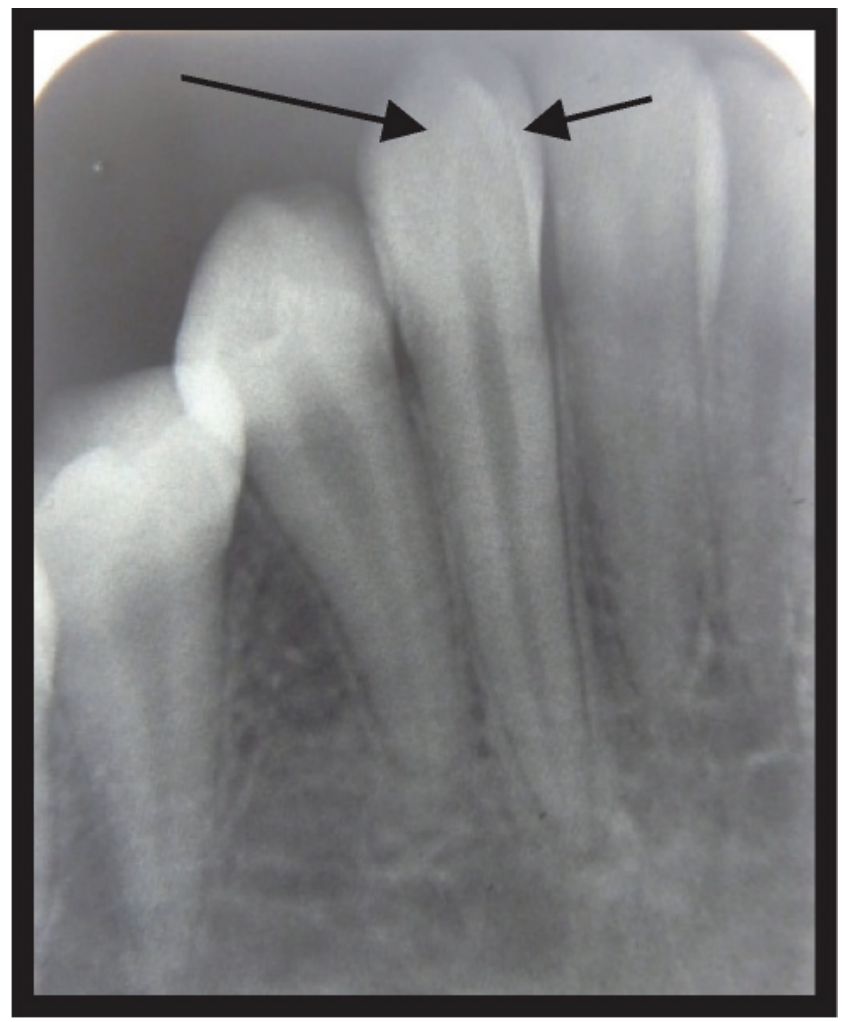

Fig. 3. IOPA of 33 showing radioopaque $V$ - shaped structure 


\section{Discussion}

In the year 1892, William Mitchell reported the first case of talon cusp in a permanent incisor, which presented an extra cusp-like structure, protruding lingually from the cingulum. ${ }^{\text {acc. }} 6$ Mellor and Ripa coined the term in 1970 because of its distinctive similarity to an eagle's talon. ${ }^{\text {acc. }} 7$ An archeological report belonging to the age of ca. 9500 BP in the Republic of Niger reported a facial talon cusp on the mandibular canine of an adult male, which was the only case report on a mandibular canine. ${ }^{8}$ Thus, this case presents a very rare form of labial talon cusp on a permanent mandibular canine.

The exact etiology of talon cusp is unknown, however it is considered to originate at some point in the morphodifferentiation stage of odontogenesis because of the hyperproductivity of the dental lamina or outfolding of the enamel organ. ${ }^{9}$

Facial talon cusp had been categorized into 3 stages by Mayes in 2007..$^{10}$

Stage 1: The mildest form, which consists of a slightly raised triangle on the facial surface of an incisor that extends the length of the crown but reaches neither the incisal edge nor the cementoenamel junction (CEJ).

Stage 2: The moderate form, which consists of a raised triangle on the facial surface of an incisor that extends the length of the crown and reaches the incisal edge but not the CEJ and can be observed and palpated easily.

Stage 3: The most extreme form, consisting of a freeform cusp on the facial aspect of an incisor that extends from the CEJ to the incisal edge.

The appearance of talon cusp may vary in shape and size and depends on the angle at which the X-ray is taken. ${ }^{11}$ It can cause additional complications like unpleasant esthetics, a predilection for caries and occlusal interferences. The occlusal interferences can be confirmed by the attrition present on the talon cusp tip. Other problems such as accidental cusp fracture, misinterpretations of radiographs, further attrition resulting in pulp exposure, damage to periodontium because of increased occlusal forces and displacement of opposing teeth have also been reported. ${ }^{12}$

Depending on the accessory cusp location, shape, size and the tooth affected, the treatment of talon cusp can be conservative or radical. The management depends upon the case. Usually no treatment is recommended for a small asymptomatic talon cusp. ${ }^{5}$ Sealing the interface of the talon and the palatal surface of the tooth concerned using a fissure sealant should be done as a preventive measure towards caries. Cusp reduction should be performed at periodic spans to promote the development of reparative dentin in cases of occlusal disturbances and unpleasant esthetics. Radiographically, if pulp extends into the talon cusp, while reducing the cusp, the clinician should be cautious to avoid accidental pulp exposure.

\section{Conclusions}

The present case report describes a rare case of talon cusp on the labial surface of a permanent mandibular canine and emphasizes that treatment is not mandatory for a talon cusp if it is asymptomatic, and treatment plans differ from case to case. Clinicians should be alert in diagnosing this unique entity, which can help in early treatment of the condition and thereby prevent any potential complications.

\section{References}

1. Kapur A, Goyal A, Bhatia S. Talon cusp in a primary incisor: A rare entity. J Indian Soc Pedod Prev Dent. 2011;29:248-250.

2. Praveen $P$, Anantharaj A, Venkataraghavan K, Rani P, Jaya AR. Talon cusp in a primary tooth: A case report. J Dent Sci Res. 2011;2:35-40.

3. Thakur S, Gupta R, Thakur NS, Gupta M. Facial talon cusp on permanent maxillary canine: A rare dental anomaly. Eur J General Dent. 2013;2:324.

4. Chinni SK, Nanneboyina M, Ramachandra A, Chalapathikumar H. A facial talon cusp on maxillary permanent central incisors. J Conserv Dent. 2012;15:87-88.

5. Sharma G, Nagpal A. Talon cusp: A prevalence study of its types in permanent dentition and report of a rare case of its association with fusion in mandibular incisor. J Oral Dis. 2014;21:1-6.

6. Bahadure RN, Thosar N, Jain ES. Management of talons cusp associated with primary central incisor: A rare case report. Int J Clin Pediatr Dent. 2012;5:142-144.

7. Mallineni SK, Panampally GK, Chen Y, Tian T. Mandibular talon cusps: A systematic review and data analysis. J Clin Exp Dent. 2014;6:408-413.

8. Stojanowski CM, Johnson KM. Labial canine talon cusp from the early holocene site of Gobero, central Sahara Desert, Niger. Int J Osteoarchaeol. 2011;21:391-406.

9. Hattab FN, Yassin OM, Al-Nimri KS. Talon cusp in the permanent dentition associated with other dental anomalies: Review of literature and reports of seven cases. J Dent Child. 1996;63:368-376.

10. Mayes AT. Labial talon cusp: A case study of pre-European-contact American Indians. J Am Dent Assoc. 2007;138:515-518.

11. Ramalingam K, Gajula P. Mandibular talon cusp: A rare presentation with the literature review. J Natural Sci Biol Med. 2011;2:225-228.

12. Hattab FN, Hazza'a AM. An unusual case of talon cusp on geminated tooth. J Can Dent Assoc. 2001;67:263-266. 